\title{
Salvianolic acid B Relieves Oxidative Stress in Glucose Absorption and Utilization of Mice Fed High-Sugar Diet
}

\author{
Bin Wang ${ }^{1,2}$, Shuping Wang ${ }^{2}$, Jin Sun ${ }^{1,2}$, Yonghui Shi ${ }^{1,2}$ and Guowei Le ${ }^{1,2^{\star}}$ \\ ${ }^{1}$ State Key Laboratory of Food Science and Technology, ${ }^{2}$ School of Food Science and Technology, Jiangnan University, Wuxi \\ 214122, Jiangsu, China \\ *For correspondence: Email: Igw@jiangnan.edu.cn; Tel: +86-510-8591-7789; Fax: +86-510-8591-7789
}

\begin{abstract}
Purpose: To evaluate the influence of Salvianolic acid B (Sal B) on oxidative stress in mice administrated with glucose, sucrose and high-sugar diet.

Methods: 40 Kunming mice were divided into four groups of 10. After a fast of $12 \mathrm{~h}$, mice were treated by oral infusion respectively with physiological saline, $20 \%$ glucose, $20 \%$ sucrose, and $20 \%$ glucose + $0.002 \%$ Sal B. Blood glucose and levels of reactive oxygen species (ROS) were determined at 0, 0.5, $1.0,1.5$, and $2.0 \mathrm{~h}$ after administration. Another 3 groups of $10 \mathrm{Kunming}$ mice each were fed with normal diet, high-sugar diet (20\% sucrose, HSD) and HSD + $0.002 \%$ Sal B. Four weeks later, the levels of ROS as well as antioxidant enzyme activity were determined.

Results: Blood ROS showed the first peak at $0.5 \mathrm{~h}$ and a higher peak at $1.5 \mathrm{~h}$ after high glucose administration. ROS were mainly produced in liver and pancreas with the utilization of glucose. Sal $B$ administration prevented increase in blood glucose and significantly $(p<0.05)$ reduced ROS produced in the process of glucose absorption and utilization, especially the latter. Sal B decrease oxidative stress induced by HSD through scavenging ROS associated with increased activity of antioxidant enzymes.

Conclusion: This study demonstrates that Sal B can decrease oxidative stress in glucose absorption and utilization in HSD mice. Thus, the findings provide a basis for a potential interventional strategy for protecting against oxidative damage induced by HSD.
\end{abstract}

Keywords: Salvianolic acid B, Blood glucose, Reactive oxygen species, Oxidative stress, Sugar diet.

Tropical Journal of Pharmaceutical Research is indexed by Science Citation Index (SciSearch), Scopus, International Pharmaceutical Abstract, Chemical Abstracts, Embase, Index Copernicus, EBSCO, African Index Medicus, JournalSeek, Journal Citation Reports/Science Edition, Directory of Open Access Journals (DOAJ), African Journal Online, Bioline International, Open-J-Gate and Pharmacy Abstracts

\section{INTRODUCTION}

Oxidative stress occurs when there is an imbalance between the production of reactive oxygen species (ROS) and the scavenging ability of antioxidants [1]. Emerging evidence indicates that excessive production of ROS is an important factor that contributes to the pathophysiology of a variety of diseases. A balance between oxidant and antioxidant intracellular systems is hence vital for cell function, regulation, and adaptation to diverse growth conditions [2].
Hyperglycemia is a widely known cause of enhanced free radical concentration, which can generate free radicals by autoxidation and glycation of proteins [3]. Elevated glucose concentration directly injures cells and induces lipid peroxidation, which is the main cause for diabetic complications [4]. Cumulative evidence showed that oxidative stress, induced by reactive oxygen derived from hyperglycemia, caused abnormal gene expression, altered signal transduction as well as the activation of pathways leading to programmed myocardial cell deaths [5]. 
Salvianolic acid B (Sal B), a potent anti-oxidant component from Salvia miltiorrhiza (SM; family: Labiatae), is responsible for many of Salvia miltiorrhiza's therapeutic actions such as the treatment of angina pectoris and cardiovascular diseases [6]. Sal B exhibits higher scavenging and antioxidant activities than vitamin $\mathrm{C}$, and significantly inhibits $\mathrm{H}_{2} \mathrm{O}_{2}$-induced matrix metalloproteinases-2 (MMP-2) mRNA and protein expression in human aortic smooth muscle cells (HASMCs) [7].

Numerous studies have reported that elevated glucose concentration may cause oxidative stress, Sal B has been demonstrated to possess antioxidant effects. The finding that increased ROS production in rat mesangial cells was induced by glucose uptake and metabolism [8] has prompted us to study the effect of Sal B on blood glucose regulation and the formation of ROS in the process of glucose absorption and utilization. Oxidative stress is essentially resulted from imbalanced energy intake and expenditure of the body from a metabolic point of view. On the basis of the first experiment, we wondered whether Sal B would have the antioxidant effect in HSD mice, which were closely associated with many cardiovascular diseases. Thus, we evaluated the effect of Sal B on ROS production and antioxidant capacity in HSD mice.

\section{EXPERIMENTAL}

\section{Materials}

Sal B was purchased from Xi'an Honson Biotechnology Co., Ltd. (Xi'an, China.). It was originally isolated and purified from dried roots of S. miltiorrhiza.

Experiments were conducted with male Kunming mice (Experimental Animal Centre to Chinese Academy of Science, 4 wk old, $20.92 \pm 1.97 \mathrm{~g}$ ). Before the study, mice in each group were fed initially with the normal diet for 1 week for adaptation. Mice were housed under conditions of controlled temperature $\left(23 \pm 2{ }^{\circ} \mathrm{C}\right)$ and humidity $(60 \%)$ with natural light. All experimental animal care and treatment followed the guidelines set up by the Institutional Animal Care and Use Committee of Jiangnan University.

\section{Experiment 1}

In the first experiment, 40 mice were randomly divided into four groups. The mice in each group were administered intragastrically with physiological saline, $20 \%$ (w/w) glucose, $20 \%$ sucrose, and $20 \%$ glucose $+0.002 \%$ Sal B 400 $\mu \mathrm{l}$, respectively, after a fast of $12 \mathrm{~h}$. Blood was collected from the tail vein into glass tubes with anticoagulant sodium heparin at 0, 0.5, 1.0, 1.5 and $2.0 \mathrm{~h}$ after administration, for the determination of blood glucose and ROS.

\section{Experiment 2}

In the second experiment, 30 mice were randomly and averagely divided into a control group (normal diet), a HSD group (20\% sucrose, w/w) and a HSD + Sal B group (HSD + $0.002 \%$ Sal B). Animals in each group were allowed free access to the test diets and water for 4 weeks. Compositions of the animal diets are listed in Table 1. At the end of the experimental periods, mice were deprived of food for $12 \mathrm{~h}$ and then they were slightly anesthetized. Blood used for the measurement of ROS was collected into glass tubes with anticoagulant sodium heparin by orbital vein puncture under anesthesia, and the mice euthanized with an overdose of anesthetic. Plasma was obtained from blood samples after centrifugation (3000 rpm for $10 \mathrm{~min}$ at $4^{\circ} \mathrm{C}$ ) and stored at $-20^{\circ} \mathrm{C}$ until analysis for the antioxidant activity. Tissues such as liver, pancreas, stomach, duodenum, jejunum and ileum were dissected out immediately, weighed, and then homogenized in tissue teflon glass Dounce homogenizers with $50 \mathrm{mM}$ physiological saline $(\mathrm{pH} 7.4)$ to obtain $10 \%(\mathrm{w} / \mathrm{v})$ whole homogenate. The homogenates were used for the determination of ROS, then they were centrifuged at $4000 \mathrm{rpm}$ for $15 \mathrm{~min}$ at $4{ }^{\circ} \mathrm{C}$ to discard any cell debris, and the supernatant was used for the measurement of superoxide dismutase (SOD), glutathione peroxidase (GSH$\mathrm{Px})$, catalase (CAT), and total antioxidant capacity (T-AOC).

\section{Measurement of ROS}

Levels of ROS were determined by luminoldependent CL measurements [9-11]. The reaction mixture contained $25 \mu \mathrm{L}$ fresh anticoagulated blood or $50 \mu \mathrm{L} 10 \%$ homogenate in $855 \mu \mathrm{L}(830 \mu \mathrm{L}$ for homogenate) KrebsHEPES ( $\mathrm{pH} 7.4$ ) buffer and $20 \mu \mathrm{L}$ horseradish peroxidase (HRP) $(12.4 \mathrm{U} / \mathrm{ml})$ as a catalyst. 100 $\mu \mathrm{L}$ luminal $(5 \mathrm{mmol} / \mathrm{l})$ was added to the reaction mixture after the initiation of CL. $10 \mu \mathrm{L}$ of 5 $\mathrm{mmol} / \mathrm{l}$ luminol was added to $400 \mu \mathrm{L}$ of PBS as a negative control. Levels of ROS were determined by measuring chemiluminescence in the integrated mode for $1 \mathrm{~min}$. Results were expressed as $\times 10^{3}$ counted photons per minute (cpm) per $1 \mathrm{ml}$ blood. Data from CL experiments were expressed as integrated area under the curve. The total amount of gross ROS produced in each tissue of control and HSD mice was calculated by gross ROS = gross weight of each 
Table 1: Composition of diet

\begin{tabular}{|c|c|c|c|c|c|}
\hline $\begin{array}{l}\text { Ingredient } \\
(\% w / w)\end{array}$ & Control & HSD & $\begin{array}{l}\text { Ingredient } \\
(\% w / w)\end{array}$ & Control & HSD \\
\hline Cornmeal $^{a}$ & 42.98 & 21.88 & Lysine & 0.25 & 0.25 \\
\hline Soybean meal $^{\mathrm{b}}$ & 24.0 & 28.24 & Methionine & 0.29 & 0.29 \\
\hline Wheat flour & 18.70 & 15.48 & Choline & 0.10 & 0.10 \\
\hline Corn bran & 9.0 & 9.0 & AIN-76 Minerals & 0.06 & 0.06 \\
\hline $\operatorname{Lard}^{\mathrm{c}}$ & 2.0 & 2.18 & $\mathrm{NaCl}$ & 0.20 & 0.20 \\
\hline $\mathrm{CaHPO}_{4}$ & 1.0 & 1.0 & AIN-76 Vitamins & 0.02 & 0.02 \\
\hline $\mathrm{CaCO}_{3}$ & 1.3 & 1.3 & Sucrose & 0.10 & 20.0 \\
\hline
\end{tabular}

Cornmeal contains $9.2 \%$ protein, $73.8 \%$ carbohydrate, and $3.5 \%$ fat. ${ }^{\circ}$ Soybean meal contains $41.5 \%$ protein, $35 \%$ carbohydrate, and $5 \%$ fat. ${ }^{\circ}$ Lard provides the following (g/100 g lard): 14:0, 2.0; 14:1, 0.3; 15:1, 0.1; 16:0, 26.5; 16:1, 3.7; 17:0, $0.5 ; 17: 1,0.4 ; 18: 0,12.1 ; 18: 1,42.5 ; 18: 2(\omega-6), 9.8 ; 18: 3(\omega-3), 0.7 ; 20: 0,0.2 ; 20: 1,0.6 ; 20: 4(\omega-6), 0.3$.

tissue $(\mathrm{mg}) \times$ ROS level per $\mathrm{mg}\left(10^{3} \mathrm{cpm} / \mathrm{mg}\right.$ tissue).

\section{Estimation of blood glucose}

Blood glucose was measured using reagent strips for a LifeScan SureStep $®$ Flexx glucose meter (Johnson and Johnson, Rochester, USA).

\section{Antioxidant activity assay}

Total protein contents were determined by the method of Lowry et al [12], using bovine serum albumin as a standard. SOD, GSH-Px, CAT activities and T-AOC were measured with the corresponding diagnostic kits (Nanjing Jiancheng Bioengineering Institute, Nanjing, PR China) according to the instructions of the manufacturer.

\section{Statistical analysis}

All results were expressed as mean \pm standard deviation. Comparisons across groups were performed by one-way analysis of variance with post hoc Tukey's test. $P<0.05$ was considered statistically significant. Pearson Test was also employed to test the correlation between antioxidant capacity and the levels of reactive oxygen species in blood and tissues of mice. Analysis was done with SPSS 13.0 (SPSS, Inc, Chicago, IL, USA).

\section{RESULTS}

\section{Experiment 1}

\section{Effect of glucose or sucrose administration on ROS production and blood glucose in mice}

The ROS production of blood increased slightly after intragastric administration with physiological saline. There was no significant difference among different time points. The level of ROS in blood showed the first peak at $0.5 \mathrm{~h}$ after glucose administration, which reached the highest peak at $1.5 \mathrm{~h}$ before decline. The level of ROS in the glucose administrated mice was significantly $(p<$ $0.05)$ higher than that of the sucrose administrated mice (Fig 1 A). There was no significant difference in blood glucose after intragastric administration with physiological saline among different time points. Blood glucose after intragastric administration with glucose and sucrose reached their highest peak at $0.5 \mathrm{~h}$, and the blood glucose after glucose administration was higher than sucrose $(p<0.05)$ (Fig 1 B).

\section{Effect of Sal B on ROS production and blood glucose in mice after oral infusion with glucose}

We found that Sal B administration did not change the trend of ROS and blood glucose in high glucose administrated mice, but reduced the level of ROS, especially in the utilization of glucose $(p<0.05)$ and prevented the increase of blood glucose $(p>0.05)$ (Fig 2A and B).

We found that ROS production by liver and pancreas increased by 35 and $100 \%$, respectively, in HSD mice, compared to control mice (Table 2). Treatment with Sal B decreased ROS production in liver by $104.05 \%$, and in pancreas by $84.65 \%$, compared to HSD mice.

\section{Effect of Sal B on antioxidant activity of HSD mice}

SOD and GSH-Px activities were significantly ( $p$ $<0.05$ ) decreased in plasma and all test tissues of HSD mice (Table 3). Sal B increased SOD and GSH-Px activities of various tissues in HSD mice. 
A

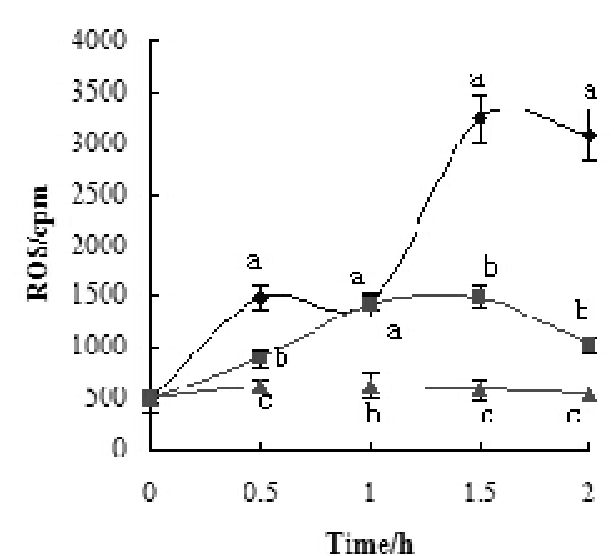

B

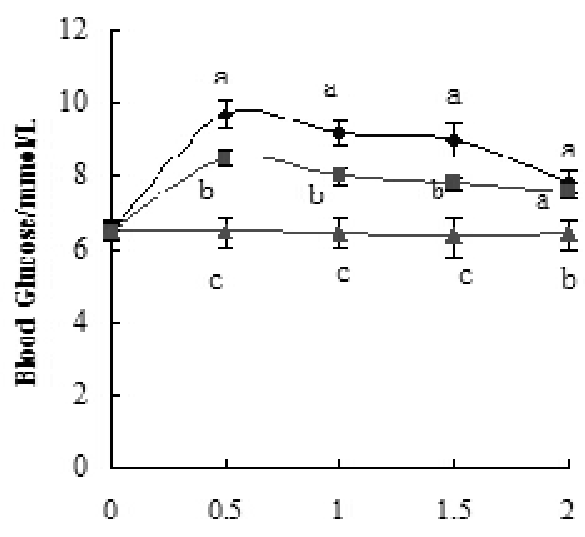

Time/h
1:

Effects of glucose or sucrose administration on the ROS and blood glucose of mice (A, B) Glucose $20 \%(\bullet)$; Sucrose $20 \%(\square)$; Physiological saline ( $\mathbf{\Delta})$. Note: Values are expressed as mean \pm SD $(n=$ 10). Mean values at the same time with different letters significantly differ at $p<0.05$.

A

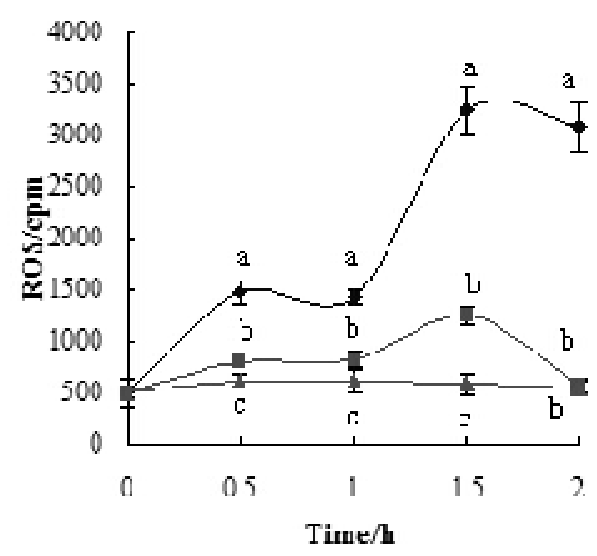

B

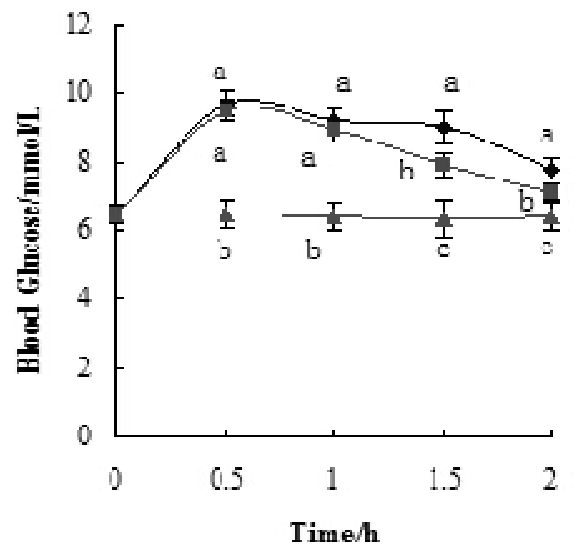

Fig 2: Effects of Sal B on the ROS and blood glucose in mice after the oral infusion of glucose $(A, B)$ Glucose $20 \%(\bullet)$; Glucose $20 \%+$ Sal B $0.002 \%(\square)$; Physiological saline ( $\mathbf{\Delta})$. Note: Values are expressed as mean $\pm S D(n=10)$. Means in the same time with different letters significantly differ at $p$ $<0.05$.

Table 2: Effect of Sal B on the level of ROS in blood $\left(10^{3} \mathrm{cpm} / \mathrm{ml}\right)$ and tissues $\left(10^{3} \mathrm{cpm} / \mathrm{mg}\right.$ tissue $)$ of control and experimental mice

\begin{tabular}{llll}
\hline Tissue & Control & HSD & HSD+Sal B \\
\hline Blood & $44.1 \pm 11.4^{\mathrm{ab}}$ & $53.1 \pm 19.3^{\mathrm{a}}$ & $30.0 \pm 9.1^{\mathrm{b}}$ \\
Liver & $288.5 \pm 60.9^{\mathrm{b}}$ & $515.4 \pm 158.0^{\mathrm{a}}$ & $279.3 \pm 61.2^{\mathrm{b}}$ \\
Pancreas & $322.8 \pm 135.8^{\mathrm{c}}$ & $599.1 \pm 93.5^{\mathrm{a}}$ & $365.2 \pm 86.8^{\mathrm{bc}}$ \\
Stomach & $255.8 \pm 167.5^{\mathrm{ab}}$ & $419.5 \pm 85.5^{\mathrm{a}}$ & $203.4 \pm 54.6^{\mathrm{b}}$ \\
Duodenum & $242.3 \pm 85.0^{\mathrm{ab}}$ & $305.3 \pm 94.2^{\mathrm{a}}$ & $124.3 \pm 32.7^{\mathrm{c}}$ \\
Jejunum & $201.6 \pm 71.5^{\mathrm{a}}$ & $213.4 \pm 59.2^{\mathrm{a}}$ & $102.7 \pm 37.2^{\mathrm{b}}$ \\
Ileum & $282.8 \pm 115.6^{\mathrm{a}}$ & $298.3 \pm 65.2^{\mathrm{a}}$ & $219.9 \pm 18.6^{\mathrm{ab}}$ \\
\hline
\end{tabular}

Note: $\mathrm{cpm}=$ counted photons per minute. Values are expressed as mean $\pm S D(n=10)$. Mean values with different superscript letters within a row are significantly different $(p<0.05)$. 
Table 3: Effect of Sal B on SOD and GSH-Px activities in plasma (U/ml) and tissues (U/mg protein) of control and experimental mice

\begin{tabular}{|c|c|c|c|c|c|c|}
\hline \multirow{2}{*}{ Tissue } & \multicolumn{3}{|c|}{ SOD } & \multicolumn{3}{|c|}{ GSH-Px } \\
\hline & Control & HSD & HSD+Sal B & Control & HSD & HSD+Sal B \\
\hline Plasma & $3.45 \pm 0.16^{b}$ & $1.68 \pm 0.24^{\mathrm{C}}$ & $3.79 \pm 0.52^{\mathrm{a}}$ & $165.66 \pm 10.64^{a}$ & $144.04 \pm 3.79^{b}$ & $155.70 \pm 6.75^{a}$ \\
\hline Liver & $60.68 \pm 2.86^{a}$ & $36.94 \pm 1.25^{c}$ & $55.68 \pm 1.33^{\mathrm{b}}$ & $5.36 \pm 0.17^{\mathrm{a}}$ & $3.51 \pm 0.57^{\mathrm{b}}$ & $5.34 \pm 0.18^{\mathrm{a}}$ \\
\hline Pancreas & $32.43 \pm 1.25^{a}$ & $15.97 \pm 1.34^{c}$ & $29.66 \pm 1.31^{\mathrm{D}}$ & $17.13 \pm 1.25^{a}$ & $11.50 \pm 1.39^{b}$ & $16.91 \pm 1.40^{a}$ \\
\hline Stomach & $28.79 \pm 0.98^{a}$ & $12.39 \pm 0.60^{c}$ & $25.59 \pm 1.38^{\mathrm{b}}$ & $6.79 \pm 0.20^{a}$ & $4.61 \pm 0.30^{\mathrm{D}}$ & $6.70 \pm 0.19^{a}$ \\
\hline Duodenum & $36.07 \pm 2.13^{a}$ & $16.79 \pm 2.26^{c}$ & $31.94 \pm 1.84^{\mathrm{D}}$ & $17.08 \pm 1.56^{\mathrm{a}}$ & $11.83 \pm 0.77^{c}$ & $15.25 \pm 0.62^{b}$ \\
\hline Jejunum & $37.92 \pm 2.27^{a}$ & $17.77 \pm 1.66^{c}$ & $29.25 \pm 4.27^{\mathrm{b}}$ & $13.66 \pm 0.30^{a}$ & $9.41 \pm 0.92^{\mathrm{b}}$ & $13.30 \pm 0.31^{a}$ \\
\hline lleum & $38.73 \pm 2.36^{a}$ & $16.46 \pm 1.50^{c}$ & $30.75 \pm 1.79^{b}$ & $5.79 \pm 0.32^{\mathrm{a}}$ & $2.91 \pm 0.20^{\mathrm{C}}$ & $4.94 \pm 0.26^{\mathrm{b}}$ \\
\hline
\end{tabular}

Note: Values are expressed as mean $\pm S D(n=10)$; means with different superscript letters within a row are significantly different $(p<0.05)$.

Table 4: Effect of Sal B on CAT activity and T-AOC in plasma (U/ml) and tissues (U/mg protein) of control and experimental mice

\begin{tabular}{|c|c|c|c|c|c|c|}
\hline \multirow{2}{*}{ Tissue } & \multicolumn{3}{|c|}{ CAT } & \multicolumn{3}{|c|}{ T-AOC } \\
\hline & Control & HSD & HSD+Sal B & Control & HSD & HSD+Sal B \\
\hline Plasma & $34.64 \pm 7.18^{\mathrm{a}}$ & $22.00 \pm 5.23^{b}$ & $30.69 \pm 2.48^{a}$ & $1.87 \pm 0.44^{\mathrm{a}}$ & $1.25 \pm 0.17^{0}$ & $1.66 \pm 0.10^{\mathrm{ab}}$ \\
\hline Liver & $7.81 \pm 1.23^{a}$ & $6.20 \pm 0.56^{a}$ & $7.68 \pm 0.83^{a}$ & $1.03 \pm 0.16^{a}$ & $0.62 \pm 0.12^{C}$ & $0.83 \pm 0.12^{\mathrm{ab}}$ \\
\hline Pancreas & $14.09 \pm 1.55^{a}$ & $9.78 \pm 1.05^{\mathrm{b}}$ & $11.97 \pm 0.58^{a b}$ & $4.52 \pm 0.32^{a}$ & $3.42 \pm 0.23^{b}$ & $4.21 \pm 0.41^{a}$ \\
\hline Stomach & $7.77 \pm 1.58^{\mathrm{a}}$ & $5.46 \pm 0.96^{\mathrm{D}}$ & $8.33 \pm 0.95^{\mathrm{a}}$ & $0.63 \pm 0.05^{a}$ & $0.45 \pm 0.04^{\mathrm{D}}$ & $0.59 \pm 0.06^{\mathrm{a}}$ \\
\hline Duodenum & $21.38 \pm 4.60^{a}$ & $15.19 \pm 1.48^{\mathrm{D}}$ & $17.10 \pm 1.58^{\mathrm{ab}}$ & $0.80 \pm 0.07^{a}$ & $0.54 \pm 0.18^{\mathrm{D}}$ & $0.57 \pm 0.08^{\mathrm{b}}$ \\
\hline Jejunum & $16.84 \pm 2.12^{\mathrm{a}}$ & $8.81 \pm 1.56^{\mathrm{c}}$ & $14.52 \pm 1.94^{\mathrm{b}}$ & $0.64 \pm 0.05^{a}$ & $0.33 \pm 0.01^{c}$ & $0.53 \pm 0.04^{\mathrm{b}}$ \\
\hline Ileum & $11.25 \pm 0.93^{a}$ & $9.70 \pm 1.12^{b}$ & $11.49 \pm 1.23^{a}$ & $0.50 \pm 0.02^{a}$ & $0.27 \pm 0.02^{b}$ & $0.51 \pm 0.04^{a}$ \\
\hline
\end{tabular}

Note: Values are expressed as mean $\pm S D(n=10)$; means with different superscript letters within a row are significantly different $(p<0.05)$.

Table 5: Pearson correlation coefficient of ROS levels and antioxidant capacity in blood and tissues of mice

\begin{tabular}{lllll}
\hline ROS & SOD & GSH-Px & CAT & T-AOC \\
\hline Plasma & $-0.438^{+}$ & -0.382 & $-0.598^{++}$ & -0.387 \\
Liver & $-0.550^{++}$ & $-0.903^{++}$ & $-0.665^{++}$ & $-0.706^{++}$ \\
Pancreas & $-0.801^{++}$ & $-0.904^{++}$ & $-0.813^{++}$ & $-0.910^{++}$ \\
Stomach & $-0.534^{++}$ & $-0.671^{++}$ & $-0.787^{++}$ & $-0.735^{++}$ \\
Duodenum & $-0.412^{+}$ & -0.427 & -0.252 & -0.157 \\
Jejunum & -0.281 & $-0.485^{+}$ & $-0.407^{+}$ & -0.321 \\
Ileum & -0.240 & -0.133 & $-0.632^{++}$ & $-0.421^{+}$ \\
\hline
\end{tabular}

\section{Experiment 2}

\section{Effect of Sal B on ROS production of HSD mice}

There was a significant $(p<0.05)$ decrease in CAT activity in all tissues of HSD mice except for liver (Table 4). Sal B treatment significantly inhibited the decrease in CAT activity in all tissues except for liver, pancreas and duodenum. Treatment of HSD mice also showed a marked decrease in T-AOC in plasma and all tissues (Table 4). Administration of Sal B greatly elevated T-AOC in all tissues of HSD group except for duodenum.

\section{Correlation assay}

As was shown by correlation assay (Table 5), there was a negative correlation between the production of ROS and the activities of antioxidant enzymes, especially in liver and pancreas. The level of ROS correlated negatively with T-AOC (liver and pancreas) where $r=$ $0.706, P<0.01$ and $r=-0.910, P<0.01$, respectively.

\section{DISCUSSION}

Acute hyperglycaemia can impair the physiological homeostasis of important systems in living organisms and may exert these effects via the production of free radicals and associated oxidative stress [13]. Ha \& Lee [8] reported increased ROS production in rat mesangial cells within $15 \mathrm{~min}$ of incubation in $30 \mathrm{mM}$ D-glucose. This increase in production was prevented by inhibiting glucose transport into the cells, and no effect of $25 \mathrm{mM}$ L-glucose or the nonmetabolizing analogue 3-O-methyl-d-glucose was seen, implying that glucose uptake and metabolism triggered the response seen. 
In our study, blood ROS increased slightly after oral infusion of physiological saline. There was no significant difference among different time points, suggesting that the release of reactive oxygen species was not affected by the course of oral administration. No significant difference of blood glucose was seen among different time points after oral infusion with physiological saline. Blood glucose rose rapidly $0.5 \mathrm{~h}$ after glucose infusion. Glucose intake could be said to be the main course of glucose absorption and appearance of the first ROS release peak, suggesting that a large amount of ROS were produced during the absorption of glucose. Blood glucose declined with the use of glucose by tissues and cells, which correlates with the second higher peak of ROS at time $1.5 \mathrm{~h}$, showing that more ROS were produced during glucose utilization. This is consistent with a previous study [8] in which cytochalasin $B$, an inhibitor of glucose transporter, effectively inhibits high glucose-induced ROS generation and suggests that glucose uptake and metabolism are required in high glucose-induced cytosolic ROS generation.

The effect of oral infusion with sucrose showed similar trend to that of glucose but with lower peak, suggesting that more ROS were produced in the absorption and utilization of glucose than sucrose. Sucrose is decomposed into the same mole of glucose and fructose in vivo before absorption under the role of sucrase, which may be the reason for the lower blood glucose peak compared to glucose administration.

It has been reported that ROS production is triggered by acute elevation of plasma glucose [14]. Elevated glucose causes increased superoxide production [15]. Sal B is composed of three danshensu units (chemical name $D-(+) \beta$ (3, 4-dihydroxyphenyl) lactic acid) and one caffeic acid unit through ester linkage and condensation at the aromatic ring of caffeic acid. Caffeic acid and its various oligomers were shown to possess different antioxidant activities. Danshensu, a monomer of caffeic acid, is the hydrated form of caffeic acid in Salvia miltiorrhiza. It was shown that condensation and conjugation of caffeic acid and its derivatives appeared to be important for antioxidant activity. Indeed Sal B has been demonstrated to protect hepatocytes against oxidative injury including lipid peroxidation and ROS formation [16]. Sal B decreases ROS production and NADPH oxidase activity induced by TNF- $\alpha$ in a dose-dependent manner [7]. In our study, high glucose infusion induced oxidative stress, while treatment with $0.002 \%$ Sal B showed a considerable decrease in blood glucose, and a significantly reduction of ROS production especially in the course of glucose absorption and utilization. Decrease in oxidative stress of diabetic subjects is mediated by improved glycemic control [17]. The implication is that the glucose control effect of Sal $B$ is significantly associated with the release of associated oxidative stress.

Hyperglycemia is a widely known cause of enhanced free radical concentration. Similar to a previous study [18], the HSD resulted in significant increase in ROS in our experiments, suggesting that the high-sugar diet evoked oxidative stress. ROS levels in liver and pancreas were higher compared to other tissues, which points to the important role of liver and pancreas in glucose metabolism. Liver produced the largest amount of ROS among all the tissues which is consistent with the findings of a previous study that more ROS are produced in the course of glucose utilization. The fact that Sal B treatment decreased ROS production indicates that it can relieve the associated oxidative stress, especially in the course of glucose utilization.

As free radical scavengers, SOD, GSH-Px and CAT exist in all oxygen-metabolizing cells, preventing cells from damage by free radicals, but their activities are significantly reduced in many oxidative stress injuries $[19,20]$. In the present study, HSD resulted in significant oxidative damage to plasma and tissues, as characterized by decreased SOD, GSH-Px and CAT activities in HSD mice. The activities of the antioxidant enzymes correlated negatively with the level of ROS in the present work, suggesting that the overproduction of ROS was significantly associated with the decrease of antioxidant enzymes. Sal B is reported to possess antioxidant hepatoprotective and antifibrogenic effects [16]. In the present study, Sal B treatment released the associated oxidative stress by eliminating ROS as well as increasing the activities of antioxidant enzymes. T-AOC reflects the capacity of non-enzymatic antioxidant defense system. Sal B treatment also increased T-AOC, suggesting that an enhanced antioxidant defense mechanism suppressed peroxidation in HSD mice.

\section{CONCLUSION}

The present study demonstrates that Sal B can considerably decrease blood glucose and ROS produced during the absorption and utilization of glucose, especially the latter. Administration of Sal B alleviates oxidative stress induced by HSD by decreasing the production of ROS and increasing antioxidant enzymes, suggesting that 
Sal B has potential to act as natural antioxidants in vivo, and thus can provide health benefits upon consumption.

\section{ACKNOWLEDGMENT}

This work was supported by the National Natural Science Foundation of China (31201805, $31172214)$, the 12th Five-Year Plan for Science and Technology Development of China (2012BAD33B05), and a project funded by the Priority Academic Program Development of Jiangsu Higher Education Institutions (PAPD).

\section{REFERENCES}

1. Lei XG, Vatamaniuk MZ. Two tales of antioxidant enzymes on $\beta$ cells and diabetes. Antioxid Redox Signal. 2011; 14: 489-503.

2. Chan SH, Chan JY. Angiotensin-generated reactive oxygen species in brain and pathogenesis of cardiovascular diseases. Antioxid Redox Signal. 2013; 19: 1074-1084.

3. Ceriello A. Oxidative stress and glycemic regulation. Metabolism. 2000; 49: 27-29.

4. Owolabi OJ, Amaechina FC, Okoro M. Effect of ethanol leaf extract of newboulda laevis on blood glucose levels of diabetic rats. Trop J Pharm Res. 2011; 10: 249-254.

5. Cai L, Kang YJ. Oxidative stress and diabetic cardiomyopathy: a brief review. Cardiovasc Toxicol. 2001; 1: 181-193.

6. Ji X, Tan BK, Zhu YC, Linz W, Zhu YZ. Comparison of cardioprotective effects using ramipril and DanShen for the treatment of acute myocardial infarction in rats. Life Sci. 2003; 73: 1413-1426.

7. Zhang HS, Wang SQ. Salvianolic acid B from Salvia miltiorrhiza inhibits tumor necrosis factor- $\alpha$ (TNFa)-induced MMP-2 upregulation in human aortic smooth muscle cells via suppression of $N A D(P) H$ oxidase-derived reactive oxygen species. $\mathrm{J}$ Mol Cell Cardiol. 2006; 41: 138-148.

8. Ha $\mathrm{H}$, Lee HB. Reactive oxygen species as glucose signaling molecules in mesangial cells cultured under high glucose. Kidney Int Suppl. 2000; 77: S19-S25.

9. Li Y, Zhu H, Trush MA. Detection of mitochondriaderived reactive oxygen species production by the chemilumigenic probes lucigenin and luminal.
Biochim Biophys Acta. 1999; 1428: 1-12.

10. Nemeth A, Jakus J, Kriska T, Keszler A, Vanyur R, Gal $D$. Physico-chemical modeling of the role of free radicals in photodynamic therapy: IV. quantitative aspects of photodynamic effects on free radicals generated in cell cultures. Biochem Biophys Res Commun. 1999; 255: 360-366.

11. Esfandiari N, Sharma RK, Saleh RA, Thomas AJ Jr, Agarwal A. Utility of the nitroblue tetrazolium reduction test for assessment of reactive oxygen species production by seminal leukocytes and spermatozoa. J Androl. 2003; 24: 862-870.

12. Lowry $\mathrm{OH}$, Rosebrough NJ, Farr AL, Randall RJ. Protein measurement with Folin Phenol reagent. J Biol Chem. 1951; 193: 265-275.

13. Ceriello A. Acute hyperglycaemia and oxidative stress generation. Diabet Med. 1997; 14: S45-S49.

14. Ceriello A, Bortolotti N, Crescentini A, Motz E, Lizzio S, Russo A, Ezsol Z, Tonutti L, Taboga C. Antioxidant defences are reduced during the oral glucose tolerance test in normal and non-insulindependent diabetic subjects. Eur J Clin Invest. 1998; 28: 329-333.

15. Yano M, Hasegawa G, Ishii M, Yamasaki M, Fukui M, Nakamura N, Yoshikawa T. Short-term exposure of high glucose concentration induces generation of reactive oxygen species in endothelial cells: implication for the oxidative stress associated with postprandial hyperglycemia. Redox Rep. 2004; 9: 111-116.

16. Lin $Y L, W u C H$, Luo $M H$, Huang $Y J$, Wang $C N$, Shiao $M S$, Huang $Y T$. In vitro protective effects of salvianolic acid $B$ on primary hepatocytes and hepatic stellate cells. J Ethnopharmacol. 2006; 105: 215-222.

17. Scott JA, King GL. Oxidative stress and antioxidant treatment in diabetes. Ann N Y Acad Sci. 2004; 1031: 204-213.

18. Ceriello A, Quatraro A, Giugliano D. New insights on non-enzymatic glycosylation may lead to therapeutic approaches for the prevention of diabetic complications. Diabet Med. 1992; 9: 297299.

19. Al-Jassabi S, Ahmed KAA, Abdulla MA. Antioxidant effect of curcumin against microcystin-LRinduced renal oxidative damage in Balb/c mice. Trop J Pharm Res. 2012; 11: 531-536.

20. Chen $X$, Zhong $H Y$, Zeng JH, Ge J. The pharmacological effect of polysaccharides from Lentinus edodes on the oxidative status and expression of VCAM-1mRNA of thoracic aorta endothelial cell in high-fat-diet rats. Carbohydr Polym. 2008; 74: 445-450. 